\title{
POLITIK HUKUM PERATURAN PEMERINTAH PENGGANTI UNDANG-UNDANG REPUBLIK INDONESIA NOMOR 1 TAHUN 2014 TENTANG PEMILIHAN GUBERNUR, BUPATI, DAN WALIKOTA
}

\section{Politics Law the Government Regulation a Substitute for the Law of the Republic of Indonesia Number 1 of 2014 on the Election of the Governor, Regent, and Mayor}

\section{Muhammad Jeffry Rananda}

Universitas Diponegoro, Semarang email: rolex_sweep_calabria@ hotmail.com

\begin{abstract}
The formation of The government regulation a substitute for the law of the Republic of Indonesia Number 1 of 2014 on the Election of Governor, Regent, and Mayor? How does the process of formation of the government regulation a substitute for the law of the Republic of Indonesia Number 1 of 2014 on the Election of Governor, Regent, and Mayor studied in the political perspective of the law? A substitute for the law of regulation making process shows again that the law is a product of politics. The fact that a political institutions, that chooses to create the rule of law. Although empirically then the law will be reset the political institutions. A substitute for the law of regulation is a Ius Constitutum as regulations on local elections. However, A substitute for the act of regulation it will not be effective because it is only temporary. A substitute for the Law of regulation attestation required then it becomes a law or made the latest Law.
\end{abstract}

Keywords: The government regulation a substitute for the Law, Legal Politics

\section{abstrak}

Pembentukan Peraturan Pemerintah Pengganti Undang-Undang Republik Indonesia Nomor 1 Tahun 2014 Tentang Pemilihan Gubernur, Bupati, Dan Walikota? Bagaimana proses pembentukan Peraturan Pemerintah Pengganti Undang-Undang Republik Indonesia Nomor 1 Tahun 2014 Tentang Pemilihan Gubernur, Bupati, Dan Walikota dikaji dalam perspektif politik hukum? Proses pembuatan Perppu tersebut menunjukkan kembali bahwa hukum merupakan produk politik. Faktanya bahwa lembaga politik lah yang memili kekuasaan untuk menciptakan hukum. Walaupun kemudian secara empiris hukum akan kembali mengatur lembaga politik tersebut. Perppu 
tersebut merupakan Ius Constitutum sebagai peraturan tentang pemilihan kepala daerah. Namun, Perppu itu tidak akan berjalan efektif karena itu hanya bersifat sementara. Diperlukan kemudian pengesahan Perppu itu menjadi sebuah UU atau dibuat UU terbaru.

Kata Kunci: Peraturan Pemerintah Pengganti Undang-Undang, Politik Hukum

\section{A. Pendahuluan}

E. Utrecht memaparkan bahwa politik hukum adalah suatu ilmu normatif yaitu ilmu yang menentukan hal-hal yang seharusnya ada. ${ }^{1}$ Sesuatu yang seharusnya ada dalam bentuk normatif adalah peraturan perundangundangan, baik yang bersifat materiil maupun formil. Politik hukum kemudian berperan untuk menentukan cara dan tujuan yang hendak dicapai dalam pembuatan ataupun pelaksanaan suatu produk hukum.

Kemudian Satjipto Raharjo mengatakan bahwa yang menjadi fokus kajian politik hukum adalah $:^{2}$ 1) Tujuan apa yang hendak dicapai dengan sistem hukum yang ada; 2) Cara-cara apakah dan yang manakah yang paling baik untuk bisa dipakai mencapai tujuan tersebut; 3) Kapankah waktunya hukum itu perlu diubah dan melalui cara bagaimana perubahan itu dilakukan; 4) Dapatkah dirumuskan suatu pola yang mapan dan yang bisa membantu kita dalam proses pemilihan tujuan serta cara-cara untuk mencapai tujuan tersebut. Moh. Mahfud MD selanjutnya membagi cakupan studi politik hukum kedalam tiga hal: ${ }^{3}$ 1) Kebijakan negara (garis resmi) tentang hukum yang akan diberlakukan atau tidak diberlakukan dalam rangka pencapaian tujuan negara; 2) Latar belakang politik, ekonomi, sosial, budaya (poleksosbud) atas lahirnya produk hukum; 3) Penegakan hukum di dalam kenyataan lapangan.

Secara singkat dapat disimpulkan bahwa politik hukum ada sebagai sarana untuk menjawab pertanyaan tentang politik pembentukan dan penegakan hukum yang telah ada dan hukum yang akan ada. Proses dalam menjawab permasalahan di atas tidak terlepas dari peran pemerintah untuk menentukan arah kebijakannya.

Ruang lingkup studi politik hukum yang telah dipaparkan di atas, kemudian akan diaplikasikan untuk mengkaji salah satu produk hukum yaitu Peraturan Pemerintah Pengganti Undang-Undang Republik Indonesia

\footnotetext{
${ }^{1}$ Otong Rosadi dan Andi Desmon, Studi Politik Hukum: Suatu Optik Politik Hukum, Edisi II, (Yogyakarta: PT. Thafa Media, 2013), hlm. 6.

${ }^{2}$ Ibid., hlm. 6-7.

${ }^{3}$ Moh. Mahfud MD, Politik Hukum di Indonesia, Cet. V, (Jakarta: PT. RajaGrafindo, 2012), hlm. 4 .
} 
Nomor 1 Tahun 2014 Tentang Pemilihan Gubernur, Bupati, Dan Walikota. Pada proses pembentukan dan pengesahannya cukup menarik untuk diperhatikan. Lahirnya produk hukum tersebut memunculkan dua asumsi, di satu sisi dapat dipandang sebagai upaya pencapaian tujuan negara, di sisi lain dipandang sebagai upaya penyelamatan nama baik pembuatnya.

Berdasarkan latar belakang yang telah diuraikan di atas, maka dirumuskan permasalahan dalam makalah ini sebagai berikut. 1) Bagaimana analisis pembentukan Peraturan Pemerintah Pengganti Undang-Undang Republik Indonesia Nomor 1 Tahun 2014 Tentang Pemilihan Gubernur, Bupati, dan Walikota? 2) Bagaimana proses pembentukan Peraturan Pemerintah Pengganti Undang-Undang Republik Indonesia Nomor 1 Tahun 2014 Tentang Pemilihan Gubernur, Bupati, Dan Walikota dikaji dalam perspektif politik hukum? Jenis penelitian dalam penulisan hukum ini adalah penelitian hukum normatif atau penelitian hukum kepustakaan yaitu penelitian hukum yang dilakukan dengan cara meneliti bahan-bahan pustaka atau data sekunder yang terdiri dari bahan hukum primer.

\section{B. Pembahasan}

\section{Analisis Pembentukan Peraturan Pemerintah Pengganti Undang- Undang Republik Indonesia Nomor 1 Tahun 2014 Tentang Pemilihan Gubernur, Bupati, dan Walikota}

Demokrasi berasal dari bahasa Yunani yaitu demokratia yang terbentuk dari kata "demos" dan "kratos" artinya kekuasaan rakyat. ${ }^{4}$ Plato menyatakan bahwa tujuan negara adalah untuk memajukan kesusilaan manusia, sebagai perseorangan dan makhluk sosial. ${ }^{5}$ Penjelasan UndangUndang Dasar 1945 menunjukkan peran negara sebagai tempat kedaulatan rakyat diserahkan, di mana kekuasaan tertingginya ada di tangan Majelis Permusyawaratan Rakyat, yang dianggap sebagai penjelmaan seluruh rakyat Indonesia. $^{6}$ Di sisi lain dikenal negara hukum yang tujuannya menyelenggarakan ketertiban hukum dengan berpedoman pada hukum (rule of law). Serta negara kesejahteraan (welfare state) bertujuan mewujudkan kesejahteraan umum dalam tatanan masyarakat, dan mencapai kemakmuran serta keadilan sosial bagi seluruh rakyatnya. ${ }^{7}$

Undang-Undang Dasar Negara Republik Indonesia Tahun 1945 memang tidak pernah menyebutkan bahwa negara harus menjalankan pemilihan langsung atau tidak. Jika mengacu pada ketentuan tersebut

\footnotetext{
${ }^{4}$ Willson, N.G., Encyclopedia of Acient Greece, (New York: Routledge, 2006) hlm. 511.

5 Ellydar Chaidi, Negara Hukum, Demokrasi, dan Konstalasi Ketatanegaraan Indonesia, (Yogyakarta: Kreasi Total Media, 2007), hlm. 9.

${ }^{6}$ Ismail, Sunny, Pergeseran Kekuasaan Eksekutif, (Jakarta: Aksara baru, 1986), hlm. 14.

${ }^{7}$ Op.Cit., Ellydar Chaidir, hlm. 10.
} 
pondasi hukum bangsa, maka pengesahan Undang-Undang Pilkada bukanlah persoalan. Namun, jika mencoba menganalisa kebijakan DPR untuk mengesahkan Undang-Undang No. 22 tahun 2014 sebagai legal policy juga dinilai merampas hak demokrasi rakyat, dan disinyalir sebagai kepentingan politik suatu kelompok, dan oleh karenanya sikap untuk mengajukan Perppu No. 1 tahun 2014 adalah tepat dalam rangka melindungi kepentingan rakyat.

Untuk menjamin Pemilihan Gubernur, Bupati, dan Walikota dilaksanakan secara demokratis sebagaimana diamanatkan dalam Pasal 18 ayat (4) Undang-Undang Dasar Negara Republik Indonesia Tahun 1945 maka kedaulatan rakyat serta demokrasi dari rakyat, oleh rakyat, dan untuk rakyat wajib dihormati sebagai syarat utama pelaksanaan Pemilihan Gubernur, Bupati, dan Walikota. Namun, demokrasi tersebut tidak memiliki kepastian dilakukan secara langsung oleh rakyat atau secara perwakilan oleh DPRD.

Kedaulatan rakyat dan demokrasi tersebut perlu ditegaskan dengan pelaksanaan Pemilihan Gubernur, Bupati, dan Walikota secara langsung oleh rakyat, dengan melakukan beberapa perbaikan mendasar atas berbagai permasalahan pemilihan langsung yang selama ini telah dilaksanakan.

Pembentukan suatu peraturan perundang-undangan tidak hanya dilihat dari tujuan atau latar belakangnya belaka. Namun, pembentukannya harus bersesuaian dengan prinsip-prinsip yang ada. Oleh karena itu, perlu dilihat prinsip-prinsip apa yang mendasari lahirnya Perppu No. 1 Tahun 2014. Banyak asas-asas yang diakui dalam pembuatan peraturan perundangundangan. Attamimi berpendapat, bahwa pembentukan peraturan perundang-undangan Indonesia yang patut, adalah sebagai berikut: ${ }^{8}$

a. cita hukum Indonesia;

b. asas negara berdasarkan atas hukum dan asas pemerintahan berdasarkan sistem konstitusi; dan

c. asas-asas lainnya.

Lebih lanjut menurut Attamimi ${ }^{9}$ membagi asas-asas hukum dalam pembentukan peraturan perundang-undangan menjadi 2 (dua), yaitu; 1) asas hukum formal; dan 2) asas hukum material. Asas hukum formal berkaitan dengan "bagaimananya" suatu peraturan, sedangkan asas material berhubungan dengan "apanya" suatu peraturan. Asas-asas formal menurut Attamimi meliputi; 1) asas tujuan yang jelas; 2) asas perlunya pengaturan; 3) asas organ/lembaga yang tepat; 4) asas materi muatan yang tepat; 5) asas dapatnya dilaksanakan; dan 6) asas dapat dikenali. Sedangkan asas-asas material meliputi; 1) asas sesuai dengan cita hukum dan norma fundamental negara; 2) asas sesuai dengan hukum negara; 3) asas sesuai dengan prinsip-

\footnotetext{
${ }^{8}$ Maria Farida Indrati S, Ilmu Perundang-Undangan, Jilid I, (Yogyakarta: Penerbit: PT. Kanisius, 2007), hlm. 254.

${ }^{9}$ Op.Cit., A. Hamid S. Attamimi, hlm. 335.
} 
prinsip negara berdasar atas hukum; dan 4) asas sesuai dengan prinsipprinsip pemerintahan berdasarkan konstitusi.

Berdasarkan asas-asas formal Perppu No. 1 Tahun 2014 telah bersesuai dengan asas organ atau lembaga yang tepat, bahwa berdasarkan Pasal 22 ayat (1) UUD 1945 yang memberikan wewenang kepada Presiden untuk membuat Perppu atas keadaan memaksa.

Pasal 2 Perppu No. 1 Tahun 2014 mengatur bahwa pemilihan dilaksanakan secara demokrasi berdasarkan asas langsung, umum, bebas, rahasia, jujur, dan adil. Demokrasi yang dilakukan berdasarkan Pasal 2 tersebut mengakui kedaulatan rakyat secara absolut. Pasal tersebut juga kemudian menegaskan bentuk demokrasi dalam pemilihan kepala daerah secara langsung oleh rakyat. Dalam perjalanannya, demokrasi dalam pemilihan kepala daerah terdapat makna ganda, apakah dilakukan secara langsung atau melalui perwakilan DPRD.

\section{Politik Hukum Pembentukan Peraturan Pemerintah Pengganti Undang-Undang Republik Indonesia Nomor 1 Tahun 2014 tentang Pemilihan Gubernur, Bupati, dan Walikota \\ a. Proses Pembentukan Perppu No. 1 Tahun 2014}

Pembatasan kekuasaan dikenal dengan teori trias politica yang dikemukakan oleh Mostesqieu. Menurut ajaran ini kekuasaan dibagi ke dalam tiga bagian yaitu: legislatif, eksekutif, dan yudikatif. ${ }^{10}$ Kekuasaan legistalif merupakan lembaga pemerintahan untuk membuat undang-undang. Kekuasaan eksekutif memiliki peran sebagai pelaksana undang-undang. Sementara itu, kekuasaan yudikatif adalah lembaga yang mengawasi jalannya pemerintahan dan negara secara keseluruhan. ${ }^{11}$ Praktik di Indonesia bahwa Presiden bersama DPR yang memiliki wewenang untuk membuat undang-undang. Sedangkan Perppu dibuat oleh presiden dalam keadaan memaksa berdasarkan amanat UUD 1945. Hal tersebut dapat dilihat bahwa hukum dibuat oleh pemegang kekuasaan yang merupakan representatif dari partai politik.

Apeldoorn misalnya mencatatkan, adanya beberapa pengikut paham bahwa hukum adalah kekuasaan. Pertama, kaum Sofis di Yunani yang mengatakan keadilan adalah apa yang berfaedah bagi orang yang lebih kuat. Kedua, Lassalle mengatakan konstitusi suatu negara bukanlah undangundang dasar yang tertulis hanya merupakan secarik kertas, melainkan hubungan-hubungan kekuasaan yang nyata di dalam suatu negara. Ketiga, Gumplowics mengatakan hukum berdasarkan atas penaklukan yang lemah

\footnotetext{
${ }^{10}$ Loc. Cit., Ellydar Chaidir.

${ }^{11}$ http://www.seputarsulut.com-Revli Orelius Mandagie, Pemisahan Kekuasaan Eksekutif, Legislatif dan Yudikatif, diakses tanggal 12 Januari 2015.
} 
oleh kuat, hukum adalah susunan definisi yang dibentuk oleh pihak yang kuat mempertahankan kekuasaannya. Keempat, sebagai pengikut aliran positivisme juga mengatakan kepatuhan kepada hukum tidak lain dari tunduknya orang yang lebih lemah pada kehendak yang lebih kuat, sehingga hukum hanya merupakan hak orang yang terkuat. ${ }^{12}$

Catatan Apeldoorn di atas dapat dilihat secara nyata pada proses lahirnya PERPPU No. 1 Tahun 2014. Proses pemilihan Presiden Indonesia periode 2014-1019 telah membentuk dua golongan partai politik yang mengadu kekuatan, yaitu Koalisi Merah Putih (KMP) dan Koalisi Indonesia Hebat (KIH). Pemilu yang kemudian dimenangkan oleh kekuatan KIH. Walaupun KIH dalam hal ini menguasai lembaga eksekutif, tetapi KMP berhasil menguasai lembaga yudikatif. Fakta tersebutlah yang kemudian membuat pergulatan politik berlanjut kepada proses pembentukan peraturan perundang-undangan.

Salah satu produk hukum hasil dari pergulatan politik antara poros KMP dan KIH adalah pembentukan Undang-Undang Nomor 22 Tahun 2014 tentang Pemilihan Gubernur, Bupati, dan Walikota yang mengatur mekanisme pemilihan kepala daerah secara tidak langsung melalui Dewan Perwakilan Rakyat Daerah. Undang-undang tersebut menimbulkan kontroversi di tengah-tengah masyarakat Indonesia. Kedaulatan rakyat telah dicederai oleh undang-undang tersebut. Hal itu terbukti karena masyarakat sebagain besar menolak pengesahan undang-undang yang telah disahkan di parlemen. Walaupun, UU No. 22 Tahun 2014 tidak bisa dikatakan inkonstitusional. Artinya tidak bertentangan dengan UUD 1945, namun bertentangan dengan kehendak rakyat.

Pekerjaan pemerintah dan pekerjaan kepemimpinan politik harus selalu berkaitan dengan memecahkan berbagai masalah, memobilisasi sumber daya, dan memperoleh persetujuan warga negara. ${ }^{13}$ Presiden Susilo Bambang Yudhoyono membuat kebijakan untuk menyelesaikan permasalahan yang timbul akibat UU No.22 Tahun 2014 dengan mengeluarkan Perppu No. 1 Tahun 2014. Kebijakan yang telah diambil oleh SBY mendapat dukungan dari masyarakat, meskipun masih ada juga yang mengritik kebijakan tersebut. Ada yang memandang bahwa kebijakan tersebut merupakan bentuk pencitraan politik. Tetapi setidaknya Perppu tersebut akan mengembalikan kedaulatan rakyat untuk berperan dalam pemilihan kepala daerah.

Fakta di atas menunjukkan hubungan konfigurasi politik dengan produk hukum yang dihasilkan. Di negara yang konfigurasi politiknya demokratis, maka produk hukumnya berkarakter responsif/populistik,

\footnotetext{
12 Op. Cit., Moh. Mahfud MD, hlm. 21.

${ }^{13}$ Philippe Nonet dan Philip Selznick, Hukum Responsif, terj. Raisul Muttaqien, cet. VII, (Bandung: PT. Nusa Media, 2013) hlm. 66-67.
} 
sedangkan di negara yang konfigurasi politiknya otoriter, maka produk hukumnya berkarakter ortodoks/konservatif/elitis. ${ }^{14}$ Konfigurasi politik diartikan sebagai susunan atau kontelasi kekuatan politik yang secara dikotomis dibagi atas dua konsep yang bertentangan secara diametral, yaitu konfigurasi politik demokratis dan konfigurasi politik otoriter. Pengertian konseptual dan indikator-indikator variabel bebas ini adalah: $:^{15}$

1) konfigurasi politik demokratis adalah susunan sistem politik yang membuka kesempatan (peluang) bagi partisipasi rakyat secara penuh untuk ikut aktif menentukan kebijaksanaan umum; dan

2) konfigurasi politik otoriter adalah susunan sistem politik yang lebih memungkinkan negara berperan sangat aktif serta mengambil hampir seluruh inisiatif dalam pembuatan kebijaksanaan negara.

\section{b. Ius Constitutum ke Ius Constituendum}

Lahir Perppu No. 1 Tahun 2014 tidak terlepas dari ketidaksesuaian cita-cita demokrasi Indonesia dengan UU No. 22 Tahun 2014. Masyarakat Indonesia merasa penting untuk ikut aktif dalam proses demokrasi secara langsung. Perppu tersebut juga dilahirkan tidak terlepas dari dorongan masyarakat untuk kembali memberikan kedaulatan penuh dalam proses demokrasi ke tangan rakyat.

Perppu No. 1 Tahun 2014 sebagai Ius Constitutum pada pengaturan pemilihan kepala daerah. Namun, PERPPU ini ditetapkan oleh Presiden dalam "hal ikwal kegentingan yang memaksa" yang harus segera diatasi, karena pada saat itu presiden tidak dapat mengatur waktunya dengan UU, yang untuk membentuknya memerlukan waktu yang relatif lebih lama dan melalui prosedur yang bermacam-macam. Perppu itu jangka waktunya terbatas (sementara), sebab secepat mungkin harus diminta persetujuan pada DPR, yaitu pada persidangan berikutnya. Apabila Perppu tersebut disetujui oleh DPR maka akan menjadi UU, sedangkan kalau tidak maka akan dicabut. ${ }^{16}$

Perppu yang hanya bersifat sementara, artinya tidak dapat diberlakukan selamanya dan pasti membutuhkan pengganti yang lebih kuat keberlakuannya. Oleh karena itu, Indonesia membutuhkan pengaturan tentang pemilihan kepala daerah (Ius Constituendum). Pengaturan dapat dilakukan dengan mengesahkan Perppu tersebut menjadi sebuah UU atau DPR dan presiden kembali merancang UU yang baru.

Abdul Hakim Garuda Nusantara mengatakan bahwa bagaimanapun hukum di Indonesia harus mengacu pada cita-cita masyarakat bangsa, yakni

\footnotetext{
${ }^{14}$ Op.Cit., Moh. Mahfud MD, hlm. 22.

${ }^{15}$ Ibid., hlm. 30-31.

${ }^{16}$ Op.Cit., Maria Farida Indrati S, hlm. 190-192.
} 
tegaknya negara hukum yang demokratis dan berkeadilan sosial. Pembangunan hukum harus ditujukan untuk mengakhiri tatanan sosial yang tidak menindas hak-hak asasi manusia, sehingga politik hukum harus berorientasi pada cita-cita negara hukum yang didasarkan pada prinsipprinsip demokrasi dan berkeadilan sosial dalam satu masyarakat bangsa Indonesia yang bersatu sebagaimana tertuang di dalam Pembukaan UUD 1945. ${ }^{17}$ Sajtipto Rahardjo berpendapat, pembangunan hukum harus memiliki makna ganda. Pertama, sebagai suatu usaha untuk memperbaharui hukum positif sendiri, sehingga sesuai dengan kebutuhan untuk melayani masyarakat pada tingkat perkembangannya yang mutakhir. Kedua, sebagai usaha untuk memfungsionalkan hukum dalam masa pembangunan, yaitu dengan cara turut mengadakan perubahan-perubahan sosial sebagaimana dibutuhkan oleh masyarakat yang sedang membangun. ${ }^{18}$

\section{Penutup}

1. Terbitnya Perppu No. 1 Tahun 2014 merupakan suatu yang harus dilakukan sebagai salah satu solusi untuk meredam keganasan politik yang ditunjukkan oleh KMP. Maka terlihat bahwa hukum itu merupakan tentang kekuasaan. KMP bisa dikatakan kuat, tetapi ada kekuatan yang lebih tinggi yaitu presiden. Proses pembuatan Perppu tersebut menunjukkan kembali bahwa hukum merupakan produk politik. Faktanya bahwa lembaga politiklah yang memiliki kekuasaan untuk menciptakan hukum. Walaupun kemudian secara empiris hukum akan kembali mengatur lembaga politik tersebut;

2. Perppu tersebut merupakan Ius Constitutum sebagai peraturan tentang pemilihan kepala daerah. Namum. Perppu itu tidak akan berjalan efektif karena itu hanya bersifat sementara. Diperlukan kemudian pengesahan Perppu itu menjadi sebuah UU atau dibuat UU terbaru. Apapun kemudian kebijakan negara dalam mengatur peraturan tentang pemilihan kepada daerah pada waktu berikutnya, peraturan tersebut harus sesuai dengan cita-cita hukum Indonesia serta tidak bisa menindas hak-hak asasi manusia.

${ }^{17}$ Moh. Mahfud MD, Membangun Politik Hukum, Menegakkan Konstitusi, cet. III, (Jakarta: PT. Rajawali Pers, 2012), hlm. 16.

${ }^{18}$ Satjipto Rahardjo, Hukum dan Perubahan Sosial, (Yogyakarta: Genta Publishing, 2009), hlm. 203. 


\section{Daftar Pustaka}

\section{A. Buku}

Asshiddiqie, Jimly dan M. Ali Safa'at, 2006, Teori Hans Kelsen Tentang Hukum, Jakarta: Penerbit Sekretariat Jenderal dan Kepaniteraan Mahkamah Konstitusi.

Attamimi, A. Hamid S., 1990, Peranan Keputusan Presiden Republik Indonesia Dalam Penyelenggaraan Pemerintahan Negara; Studi Analisis Mengenai Keputusan Presiden yang Berfungsi Pengaturan dalam kurun Waktu Peita I-Pelita IV. Disertasi, Jakarta: Pasca Sarjana UI.

Chaidir, Ellydar, 2007, Negara Hukum, Demokrasi, dan Konstalasi Ketatanegaraan Indonesia, Yogyakarta: Kreasi Total Media.

Farida Indrati, Maria, 2007, Ilmu Perundang-Undangan, Jilid I, Yogyakarta: Penerbit: PT. Kanisius.

Kelsen, Hans, 1961, General Theory of Law and State, New York: Russel and Russel.

Mahfud MD, Moh, 2012, Politik Hukum di Indonesia, Cet. V, Jakarta: PT. Raja Grafindo.

2012, Membangun Politik Hukum, Menegakkan Konstitusi, cet. III, Jakarta: PT. Rajawali Pers.

Nonet, Philippe dan Philip Selznick, Hukum Responsif, terj. Raisul Muttaqien, 2013, cet. VII, Bandung: Penerbit: PT. Nusa Media.

N. G., Willson, 2006, Encyclopedia of Acient Greece, New York: Routledge. Rahardjo, Sajitpto, 2006, Ilmu Hukum, cet VI, Bandung: Citra Aditya Bakti.

Penerbit: Genta Publishing.

Rosadi, Otong dan Andi Desmon, 2013, Studi Politik Hukum: Suatu Optik Politik Hukum, Edisi II, Yogyakarta: PT. Thafa Media.

Sunny, Ismail, 1986. Pergeseran Kekuasaan Eksekutif, Jakarta: Aksara Baru.

\section{B. Internet}

http://www.seputarsulut.com-Revli Orelius Mandagie, Pemisahan Kekuasaan Eksekutif, Legislatif dan Yudikatif, diakses tanggal 12 Januari 2015. 